\title{
Preliminary Investigation on Flowering and Fruiting Pattern in a Plantation Grown Afzelia africana Sm Stand in Umuahia, Nigeria
}

\author{
Joseph O. Ariwaodo, Joy L. Harry-Asobara* \\ Forestry Research Institute of Nigeria, Eastern Research Station, Umuahia, Nigeria \\ Email: *jlhasob@gmail.com
}

Received 2 January 2015; accepted 19 January 2015; published 23 January 2015

Copyright (C 2015 by authors and Scientific Research Publishing Inc.

This work is licensed under the Creative Commons Attribution International License (CC BY).

http://creativecommons.org/licenses/by/4.0/

(c) (i) Open Access

\begin{abstract}
Research work on the improvement and breeding of indigenous hardwood species in Nigeria started about four decades ago. Such studies prove to be fruitful in planning various conservative programme specific to different habitats. The present preliminary study focuses on the flowering and fruiting pattern of a 5 year old Afzelia africana artificial forest at Eastern Research Station, Umuahia, Abia State, Nigeria. The parameters observed were phenology, flowering intensity, floral biology, fruit set and floral visitors. Flowering was first observed in 2012 (three years after planting) and subsequently in 2014 (five years after planting), although no fruit was set until 2014. All the processes of flowering to fruiting took place between January to August, with flowering peak occurring in March. The flowering intensity was very low, ranging among 286, 138, and 54, with a very low flower to fruit ratio. It is presumed that the relative young age of the trees and reduced population size amongst other probable factors may have accounted for this observation. This study is the first record of flowering and fruiting pattern of this species at plantation level in Nigeria. By late July/August, matured fruits were ready for harvest.
\end{abstract}

\section{Keywords}

Afzelia africana, Floral Biology, Phenology, Pollination, Reproductive Biology

\section{Introduction}

Afzelia Smith is a small tropical genus belonging to the family Caesalpinaceae. It is represented in Nigeria by

${ }^{*}$ Corresponding author.

How to cite this paper: Ariwaodo, J.O. and Harry-Asobara, J.L. (2015) Preliminary Investigation on Flowering and Fruiting Pattern in a Plantation Grown Afzelia africana Sm Stand in Umuahia, Nigeria. American Journal of Plant Sciences, 6, 219227. http://dx.doi.org/10.4236/ajps.2015.61025 
four tree species: Afzelia pachyloba, Afzelia bipindensis, Afzelia bella and Afzelia africana. The species, Afzelia africana Sm (Counter wood tree) understudy is commonly found in the Savanna fringing forests and drier parts of the forest region in Nigeria [1]. It is the most valuable in terms of economic importance among the occurring tree species. The root, bark and seeds are useful for medicinal purposes: antipyretic, gastrointestinal stimulant, aphrodisiac, oedema, hemorrhage amongst others [2]. The seed is edible and often sold in local markets as a thickner in soup preparation. The wood is termite resistant and is used for constructing furniture, mortars, cooking utensils, firewood and charcoal. A dyestuff called "Afzelin" has been isolated from the wood pores which may cause discolouration of fabrics, papers etc.

A relative number of studies on reproductive biology of tropical species from natural forest ecosystem has been reported by some authors [3]-[6]. In plants, reproductive biology mainly focuses on flowering phenology, floral biology, pollen-pollinator interaction, breeding systems and gene flow through pollen and seeds [7]. Flowering studies in tropical hardwood species help to provide vital information for the natural regeneration of existing stands and for the establishment of artificial plantations. In general, phenological behavior of the indigenous tree species in Nigeria is lacking in literature. [8] had noted the need for a comprehensive study on flowering and fruiting of local tree species throughout their natural range to facilitate the breeding of new cultivars of trees. In view of the dearth of information on reproductive biology which is a useful apparatus in any conservation approach, a study was initiated in 2009 to investigate the flowering and fruiting pattern of A. africana in Umuahia, Abia State, Nigeria. This paper forms a part of a series of other intended study aimed at examining the reproductive behavior of plantation grown A. Africana Sm from seedling stage to flowering, fruiting and seed collection phase.

\section{Materials and Methods}

\subsection{Study Area}

The Forestry Research Institute of Nigeria, Eastern Research Station, Umuahia, Abia State, Nigeria, lies on latitude $5^{\circ} 32$ ' $\mathrm{N}$ and longitude $7^{\circ} 29^{\prime}$ along Umuahia/Ikot-ekpene road, Umuahia, at an altitude of over $122 \mathrm{~m}$ above sea level (Figure 1). The rainfall pattern is bimodal with peaks around June to July and September to October. Annual rainfall is $2238 \mathrm{~mm}$. Minimum and maximum temperatures are $23^{\circ} \mathrm{C}$ and $30^{\circ} \mathrm{C}$ respectively. Relative humidity is $86.4 \%$. The vegetation has been described as high forest and soil type is sandy loam [9]. The parent material is the Precambrian basement complex.

\subsection{Study Site}

The mini-plantation of A. africana was established in 2009 at an espacement of $5 \mathrm{~m}$ by $5 \mathrm{~m}$ ( 0.5 hectare) from seedlings raised from seeds in the nursery unit. Phenological observations on stages of flower development from flower bud initiation to anthesis were carried out in the five year old plantation. Though initial observation of flowering occurred in 2012 (three years after planting) with complete abortion of all flowers recorded.

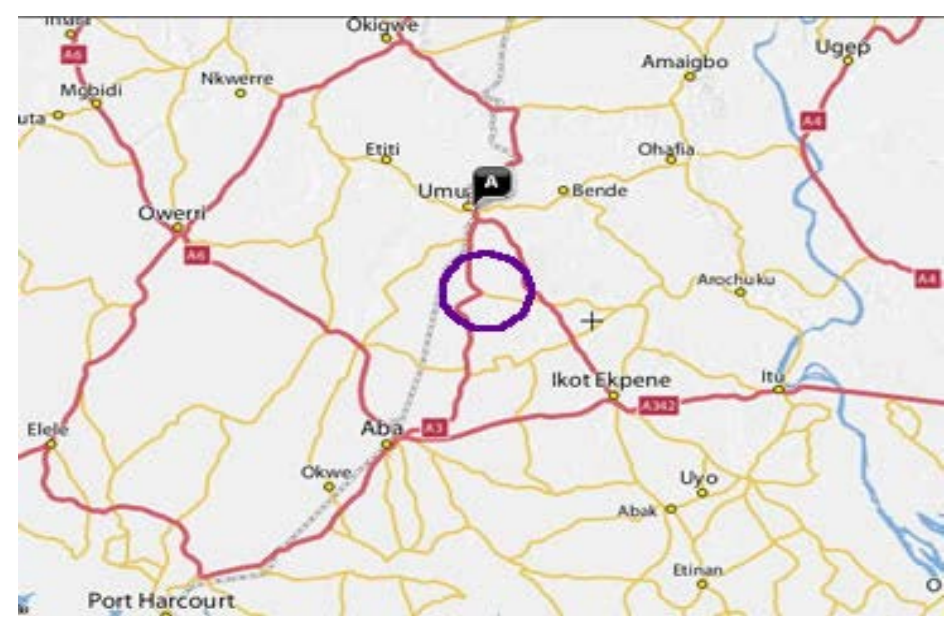

Figure 1. Map of Nigeria showing the geographical location of Umuahia. 


\subsection{Data Collection}

Observations were made weekly on selected three tagged flowering trees of A. africana in the site. The parameters observed were as follows:

a) Timing and duration of flowering

The commencement and termination of flowering among the sample trees of A. africana were noted.

b) Estimation of flowering intensity

This refers to the quantity of flowers produced by a tree per unit time, and was estimated for each of the three flowering trees selected. For each of the trees, the following parameters were recorded:

i) Total number of branches per tree

ii) Total number of branches carrying flowers/tree

iii) Total number of twigs/branch

iv) Number of twigs having flowers/branch

v) Number of twigs without flowers/branch

vi) Total number of spikes/10 twigs

vii) Total number of florets/10 spikes

c) Floral biology

The length and width of the flower buds were noted. Number of filaments, length of filaments and length of anther were measured. Length of sepals, petals, style and pedicel were also registered.

d) Identification of floral visitors

During the flowering period, the sample trees were observed for floral visitors, purpose of visiting and interaction with flowers were properly recorded, captured and identified.

e) Observation on fruit set

Commencement of fruiting as well as the developmental changes of the fruits till dehiscence was monitored. Fruit length, width and breadth; pedicel length and changes in fruit colour with maturity were all registered. Number of seeds per fruit as well as seed length and width were also noted.

\section{Results}

\subsection{Phenology}

The average height of the trees studied was $2.0 \mathrm{~m}$ with an average diameter (DBH) of $0.7 \mathrm{~m}$. The average crown diameter was $3.2 \mathrm{~m}$, not too dense, but had large irregular branches (Figure 2(a)). The flower bud development started in late January and began to open by early March of the same year. Flowering continued till April (Figure 2(b)). Flowering peak was observed from the first week of March to the fourth week of March. Flowering showed a decline from the first week of April and by the end of April, there was a complete disappearance of flowers. However, these flowers produced very less fruits. Fruiting was observed by late March and only

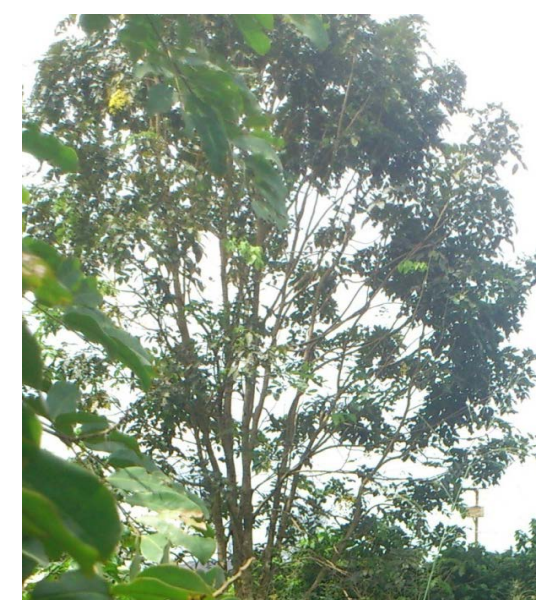

(a)

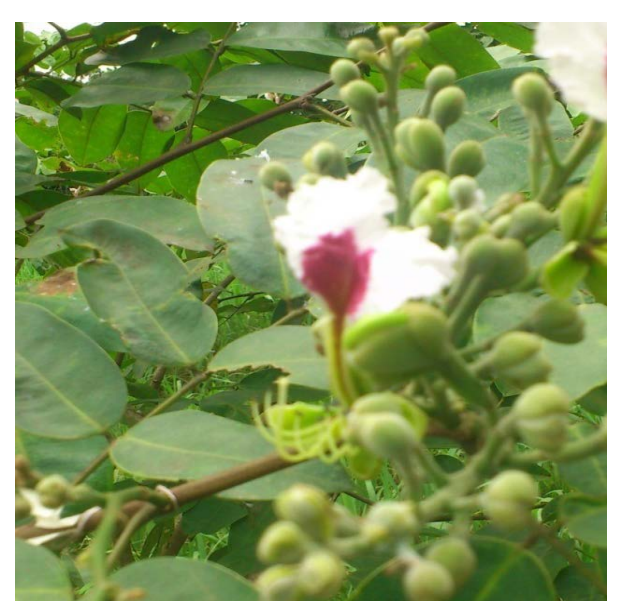

(b)

Figure 2. (a) \& (b) showing tree and floral part of A. africana at Umuahia. 
three fruits were set on one tree out of the three trees studied, indicating very low flower to fruit ratio. By late July to August, the matured fruits were dehisced, ready for seed dispersal. This was the first record of fruiting by the tree species since establishment of the mini-plantation. Figure 3(a) and Figure 3(b) present details of phenological events as well as the graphical illustration of the flowering pattern of the plantation grown stands of $A$. africana respectively.

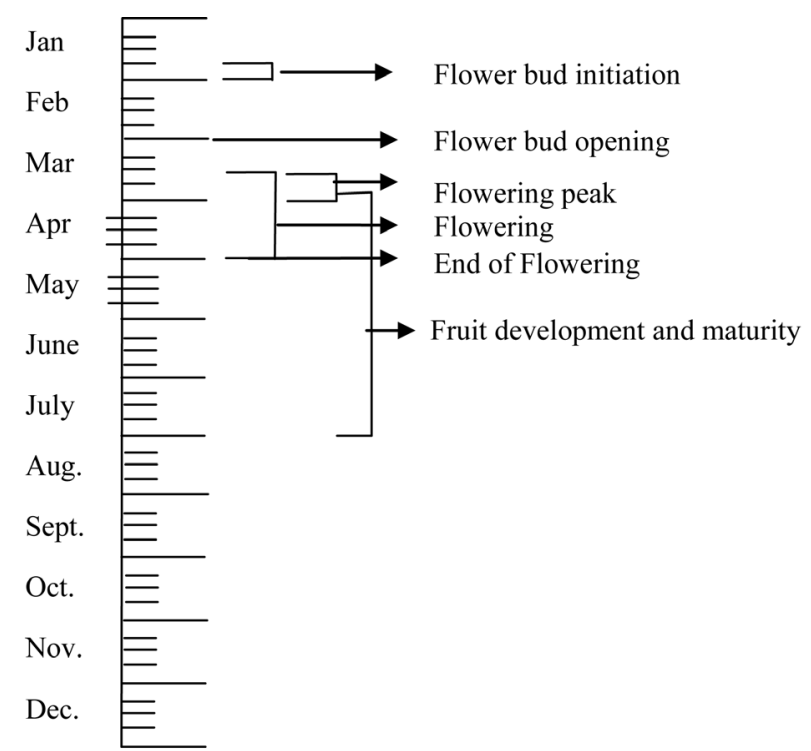

(a)

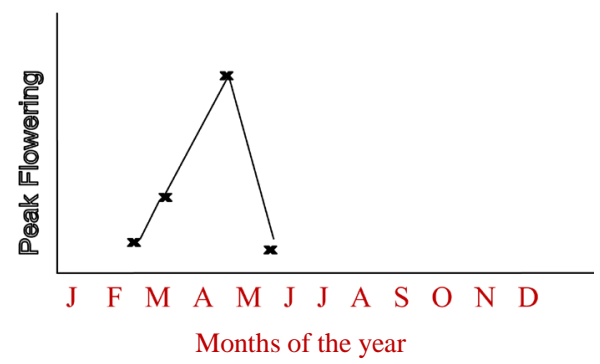

(b)

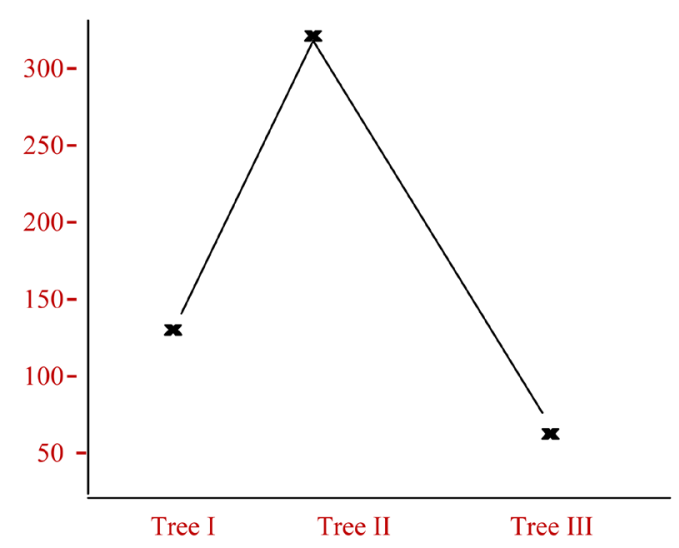

(c)

Figure 3. (a) Schematic diagram depicting different phenological events in A. africana stand in Umuahia; (b) Graphical illustration of the flowering pattern of the plantation grown stands of A. africana; (c) Graph depicting flowering intensity of plantation grown A. afzelia stand. 


\subsection{Flowering Intensity}

The total number of florets (flowers) per tree varied among the three tagged trees examined within the study site. Tree II had the maximum of 286 while tree III had the least value of 54 as shown in Table 1. Graphical illustration was further shown in Figure 3(c).

\subsection{Floral Biology}

The floral traits of A. africana as observed in this study are presented in Table 2. The total number of flowers per inflorescence ranged from 5 - 15. Each day an average number of 2 - 5 flowers per inflorescence opened at the peak of the flowering period. Inflorescence had several small branches and the flowers were arranged close together on it. The calyx was markedly tubular at the base with four concave calyx lobes (four greenish yellow sepals) arranged in two opposite pairs (Figure 4(a)). There was a conspicuous long white petal with deep red marks, broad at the top and narrowed at the base into a stalk. There were an average number of seven (7) long stalked prominent stamens, with average filament length of $7 \mathrm{~cm}$ (Figure 4(b)) and an ovary of one carpel. It took about three weeks from flower bud initiation to flower anthesis (Figure 4(c)), with average length and width of flower buds ranging from $0.3-1.2$ and 0.3 - 1.5 respectively. Anthesis was observed between 9.00 GMT and 12.00 GMT. The flowers had very high abortion rate as the flowers that did not set fruits abscised within 3 - 5 days.

\subsection{Fruit Set}

Details of fruit set are presented in Table 3. Young fruits were green, thin-walled with an average length of 2.8 $\mathrm{cm}$ and average width of $1.5 \mathrm{~cm}$ (Figure 5(a)). The fruits steadily increased in thickness with the matured fruits

Table 1. Flowering intensity of the flowering trees of A. Africana.

\begin{tabular}{cccc}
\hline Parameters & Tree I & Sample Trees & Tree III \\
\hline Bn & 2 & 6 & 3 \\
BFn & 1 & 4 & 1 \\
T/B & 18.5 & 2.5 & 3.6 \\
TF/B & 4.5 & 1.2 & 2.3 \\
T-F/B & 14.0 & 1.3 & 1.3 \\
S/T & 6.6 & 95.2 & 11.7 \\
F/S & 23.3 & 3.1 & 3.6 \\
Fn/T & 138 & 286 & 54 \\
\hline
\end{tabular}

Keys: $\mathrm{Bn}=$ Total number of branches per tree; $\mathrm{BFn}=$ Number of branches carrying flowers per tree; $\mathrm{T} / \mathrm{B}=$ Total number of twigs per branch; $\mathrm{TF} / \mathrm{B}=$ Number of twigs having flowers per branch; T-F/B = Number of twigs without flowers per branch; $\mathrm{S} / \mathrm{T}=$ Total number of spikes per 10 twigs; F/S = Total number of florets per 10 spikes; Fn/T = Total number of flowers per tree.

Table 2. Floral traits of A. africana.

\begin{tabular}{cc}
\hline Parameters & Observations $(\mathrm{cm})$ \\
\hline Average number of filaments & 7.0 \\
Average length of filaments & 3.0 \\
Average length of anther & 0.2 \\
Average length of sepals & 1.8 \\
Average width of sepals & 1.2 \\
Average length of petals & 3.6 \\
Average width of petals & 2.3 \\
Average length of style & 3.8 \\
\hline
\end{tabular}




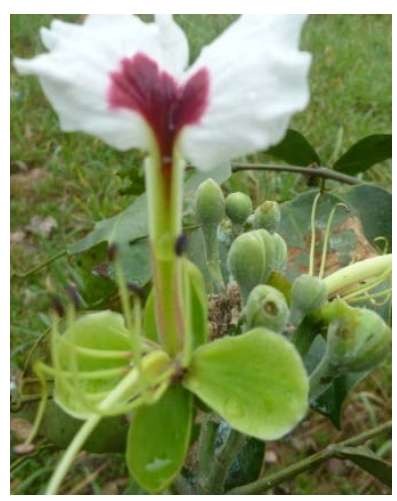

(a)

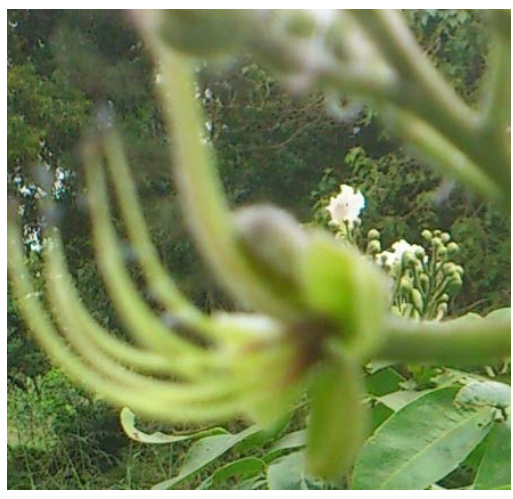

(b)

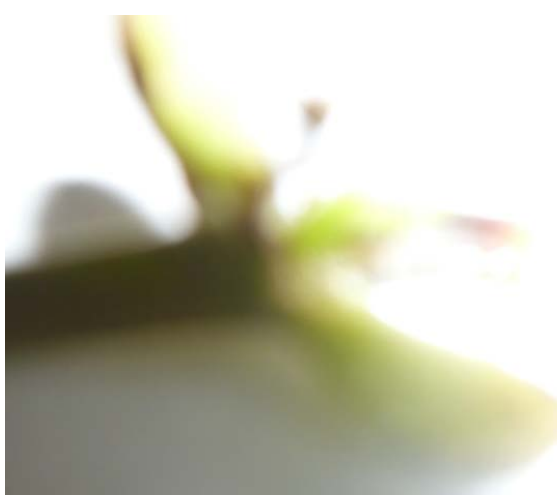

(c)

Figure 4. Flower characteristics of A. africana. (a) Calyx showing greenish yellow sepals and long white petal; (b) Long stalked stamens, revealing the filaments; (c) Asingle flower 10 hours after anthesis.

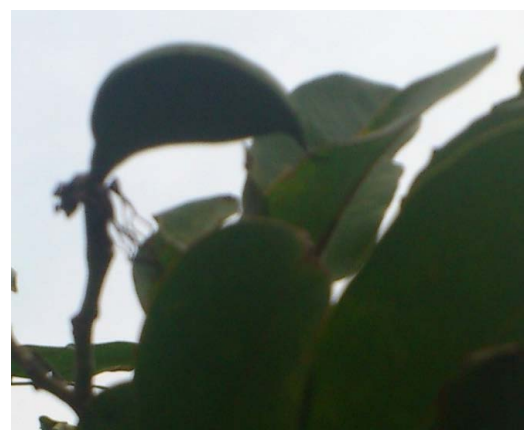

(a)

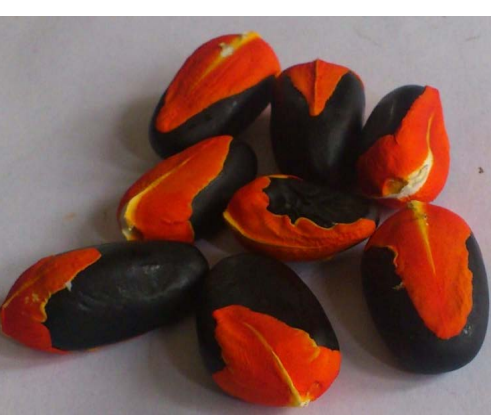

(d)

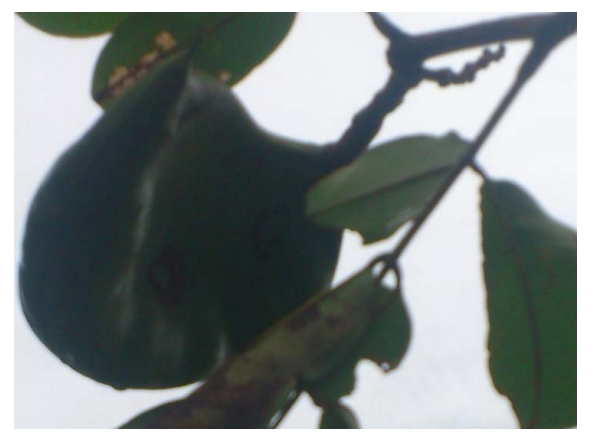

(b)

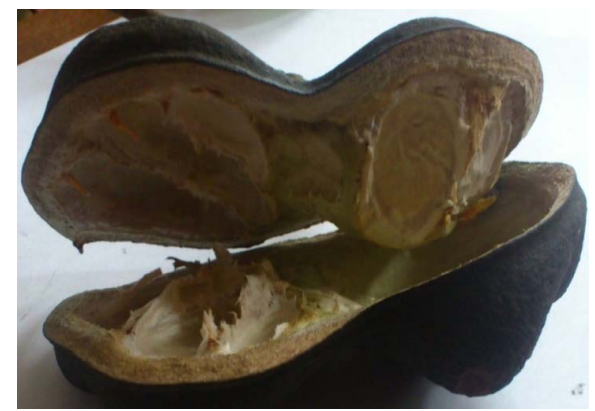

(e)

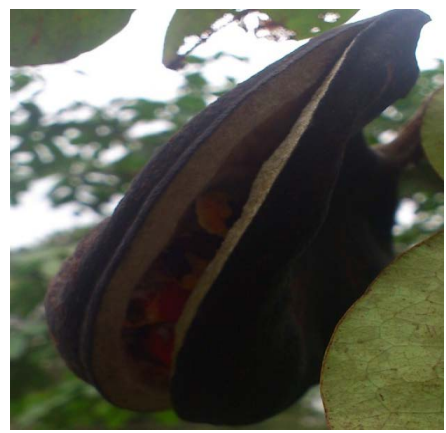

(c)

Figure 5. The fruit and seeds of A. africana. (a). A young fruit during the early fruiting stage; (b) A matured fruit prior to dehiscence; (c) A dehisced fruit ready for seed dispersal; (d) Seeds of A. africana; (e) An empty pod after seed removal.

Table 3. Fruiting characteristics of A. Africana.

\begin{tabular}{ccc}
\hline Fruit/Seed Attributes & Range $(\mathrm{cm})$ & Mean $(\mathrm{cm}) \pm$ S.E. \\
\hline Fruit length & $12.5-14.5$ & $13.47 \pm 0.54$ \\
Fruit width & $7.0-8.5$ & $7.83 \pm 0.50$ \\
Fruit thickness & $2.5-4.5$ & $3.5 \pm 0.60$ \\
Pedicel length & $6-15$ & $9.7 \pm 1.25$ \\
Number of seed & $5-8$ & $6.3 \pm 0.72$ \\
Seed length & $2.5-3.3$ & $3.1 \pm 0.24$ \\
Seed width & $1.2-1.7$ & $1.5 \pm 0.22$ \\
\hline
\end{tabular}

S.E. $=$ Standard Error. 
appearing black, thick-walled with woody pod (Figure 5(b)). The average matured fruit length was $13.5 \mathrm{~cm}, 8.0$ $\mathrm{cm}$ wide and $3.5 \mathrm{~cm}$ thick and had an average pedicel length of $9.7 \mathrm{~cm}$. The fruits hung on the tree for many months before opening to release the shinning black "mahogany bean" seeds (Figure 5(c)). Each pod contained about 7 seeds on the average. Matured seeds had an orange aril forming a somewhat fleshy cup around its base (Figure 5(d)), measuring about $7 \mathrm{~cm}$ in length on the average, with an average width of $1.4 \mathrm{~cm}$.

\subsection{Floral Visitors}

The flowers were visited by bees, butterflies, grasshoppers and cored bugs. Bees and butterflies more frequently visited the flowers in the morning. Bright colour and odour of flowers attracted the pollinators towards the flower after anthesis. Occasionally, it was observed that ants, houseflies, and grasshoppers also visited the flowers towards the afternoon. Leaf defoliation was observed on the trees and could be linked to the activities of the grasshoppers. However, on the basis of visitation rates, it could be affirmed that honey bees and butterflies were the effective pollinators of the plants. Pictures of some of the floral visitors are presented in Figure 6.

\section{Discussion}

The most crucial stages in the life cycle of any plant include reproduction, dispersal of seeds, germination followed by seedling establishment [10]. Detailed information on phenological studies helps in the conservation as well as framing effective measures for successful conservation of a species [11] [12]. A. africana is a self incompatible plant with comparatively low reproductive output. The predominant self incompatibility nature of forest trees is directly related to selective pressure to maintain genetic variability [3]. It is a trait of hermaphroditic species and is the most efficient method of controlling self pollination and thereby inbreeding in higher plants [13]. Hand pollination result in more fruit set than natural pollination. Pollination deficit in most tree species is mainly attributed to lack of pollinators or lower effectiveness of the pollinators. Bees are known for less effective pollinators since they are generalist, collecting pollen from various pollen resources resulting in the heterospecific pollen on the stigmatic surface [14]. Habitat loss and excessive pesticide usage may be the reasons for low number of pollinators [15]. Forest destruction and fragmentation may often cause damage to di-

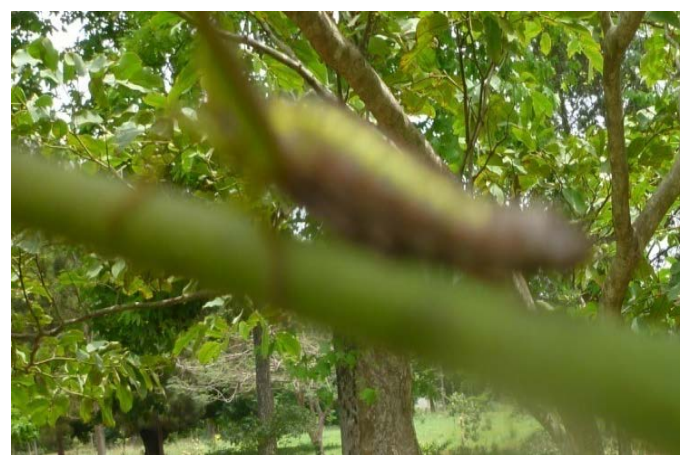

(a)

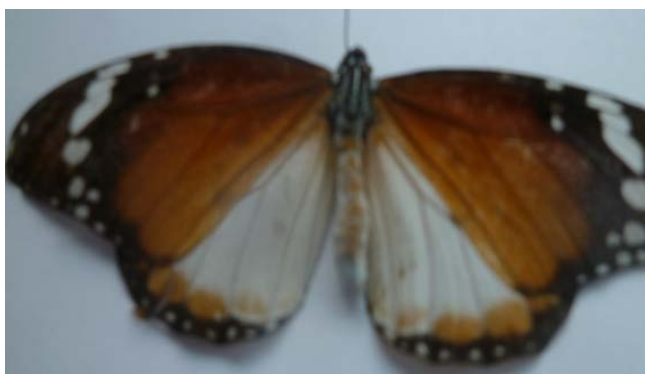

(d)

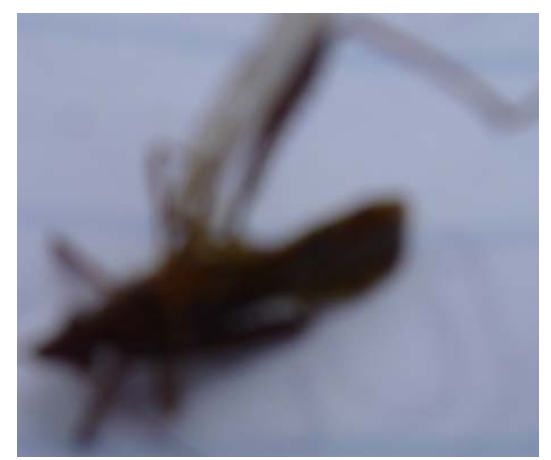

(b)

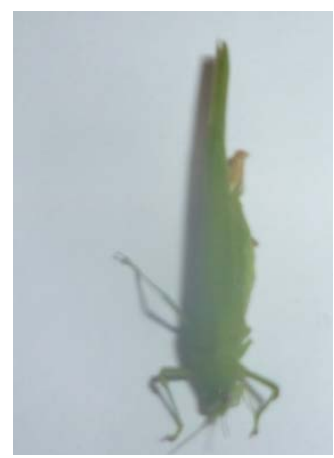

(c)

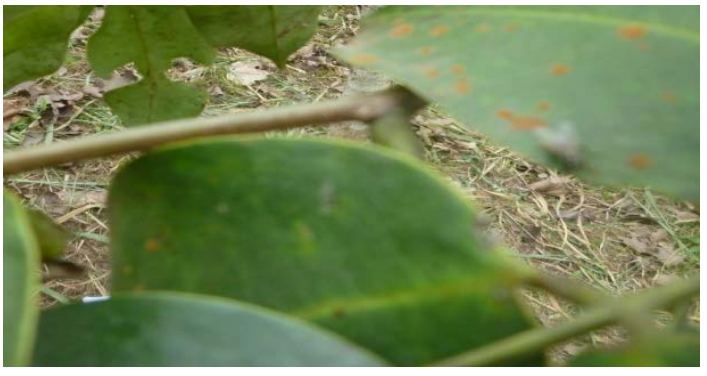

(e)

Figure 6. Some of the floral visitors observed on the sample trees of A. africana during the study period. (a) Cored bug observed feeding on the tree bark. (b) Bee, agent of pollination. (c) Grasshopper observed defoliating the leaves. (d) Butterfly, another agent of pollination. (e) Housefly, also seen perching on the trees. 
verse pollinators.

Pollen production in a plant depends upon several factors including season, anther length, pollen grain size and mode of anther dehiscence [16]. Recent studies showed that effects of pollen quantity and quality on reproductive success have become an important issue in plant conservation [17]. Although in this study, specific studies were not conducted to test for pollen viability, the failure of high rate of transformation from flower to fruit observed could be indicative of reduced pollen viability. Other probable reasons for reduced fruit set include low pollen loads on stigma, the absence of pollen tubes at the base of the style, small population size, space limitation, genetic load and climatic change [18]-[20]. The intensity of flowering reflects the amount of plant resources allocated to reproductive process. Thus the more the quantity of flowers produced by a tree, the more the quantity of pollen that will be available for pollination. Compared with the mean number of flowers per tree of 107,294; 617,018; 209, 834 and 238,685 in Terminalia ivorensis [6] and 18,102; 15,438 and 23,541 in Pittosporum dasycaulon [7], the mean quantities of flowers produced by the sample trees of A. africana (286, 138, and 54) are too low to permit appreciable level of fruit set after losses to agents of flower abortion and pollen feeders. However, duration of flowering in A. africana (3 months) appears long enough to permit the collection of genetic materials for improvement and hybridization work [7]. Also the relative young age of the trees (five years) may account for low flower production. [21] observed that variation in genetic composition and age structure affects flowering of population of plants. It was further postulated by [22] that in artificial forest and seed orchards as studied, effective breeding population sizes are reduced due to lack of flowering synchrony.

The earlier maturity period of A. africana in this study as compared to a similar study conducted in Ibadan, Oyo State, Nigeria by [23] may be due to environmental differences between the present study site in the South East and Ibadan in the South West. In her report, collection of matured, ripened fruits started in September, while the fruits started dropping in October. Flowering, she also noted occurred annually during the periods of study (2001-2003). From our study, flowering in this species was first observed in 2012 (three years after planting) with a repeat in 2014 (five years after planting) having a flowering interval of two years. No fruit was set during the first flowering until the second flowering. Thus in Umuahia, the appropriate time to collect matured fruits of A. africana on the tree is July/August. This is to ensure collection of good and healthy seeds. According to [24], seeds collected from the ground loose viability very fast in storage. However, for immediate planting, the seeds can be collected from the ground without much loss of viability. In this case, the already dehisced fruits could be allowed to disperse the seeds which could take longer than August.

\section{Conclusion}

This preliminary investigation reveales that A. africana flowers biennially in Umuahia, with flowers obtained between March and April. The flower anthesis was observed between 9.00 GMT and 12.00 GMT. The flowering intensity was low with a very low flower to fruit ratio. Fruit set began by March and matured fruits were ready for harvest from late July to August, thus the appropriate time for seed collection for storage. Our study revealed the presence of some floral visitors like bees, butterflies, cored bugs and grasshoppers. The low fruit set in this species strongly suggest the requirement of some external agents necessary for effective pollination. Since this report is preliminary, subsequent investigation on the reproductive biology of this species in this area over time is suggested. This is important because the evolutionary success and survival of this tree are largely determined by the efficacy of its reproductive performance.

\section{References}

[1] Keay, R.W.J. (1989) Trees of Nigeria. Revised Edition, Clarendon Press, Oxford.

[2] Arbonnier, M. (2002) Trees, Shrubs and Lianas of West African Dry Zones. CIRAD Margraf Publ. GmBH.

[3] Bawa, K.S. (1974) Breeding System of Tree Species of a Lowland Tropical Community. Evolution, 28, 85-92. http://dx.doi.org/10.2307/2407241

[4] Bawa, K.S. (1977) The Reproductive Biology of Cupania guatemalensis Radik (Sapindacease). Evolution, 31, 52-63. http://dx.doi.org/10.2307/2407544

[5] Bawa, K.S., Perry, D. and Beach, J.H. (1985) Reproductive Biology of Tropical Lowland Rainforest Tree (1): Sexual Systems and Incompatibility Mechanism. American Journal of Botany, 72, 331-345. http://dx.doi.org/10.2307/2443526

[6] Oni, O. (1985) Patterns of Flowering and Pollen Viability Studies in Obeche Triplochiton scleroxylon K. Schum. M.Sc Thesis, University of Ibadan, Ibadan, 98. 
[7] Gopalakrishnan, K.K. and Thomas, T.D. (2014). Reproductive Biology of Pittosporum dasycaulon Miq., (Family Pittosporaceae) a Rare Medicinal Tree Endemic to Western Ghats. Botanical Studies, 55, 15. http://dx.doi.org/10.1186/1999-3110-55-15

[8] Otegbeye, G.O. and Oje, S.O. (1995) Seed Collection and Handling Activities of Savannah Forestry Research Station, Seed Section, Nigeria. Forest Genetic Resources, No. 23, FAO, Rome, 9-13.

[9] Okeke, A.I., Asiegbu, J.E. and Ariwaodo, J.O. (1995) The Effect of Spacing on the Growth and Yield of Pinus caribea Morlet and Gmelina arborea Roxb in a Pine: Gmelina Mixed Plantation. Nigerian Journal of Forestry, 1-2, 75-82.

[10] Kavanagh, K. and Carleton, T.J. (1990) Seed Production and Dispersal Patterns in Populations of. Liriodendron tulipifera at the Northern Edge of Its Range in Southern Ontario Canadian. Canadian Journal of Forest Research, 20, 14611470. http://dx.doi.org/10.1139/x90-193

[11] Delanoe, O., Montmollin, B. and de Olivier, L. (1996) The IUCN/SCC Mediterranean Islands Plant Specialist GroupConservation of Mediterranean Island Plants. Strategy for Action Gland, Switzerland IUCN, Gland.

[12] Wafai, B.A., Siddique, M.A.A., BeighShowket, Y. and Dar, N.A. (1996) Reproductive Biology of Patris (Aconitum heterophyllum Wall. ex. Royle; Ranunculaceae) an Important Rare and Threatened Himalayan Drug Plant. HUFIUFRO International Workshop on Prospects of Medicinal Plants, Y.S. Parmer, University of Agricultural Sciences, Solan, H.P., India.

[13] Mandujano, M.C., Carrillo-Angeles, I., Martınez-Peralta, C. and Golubov, J. (2010) Reproductive Biology of Cactaceae. In: Ramawat, K.G., Ed., Desert Plants, Springer-Verlag, Berlin, 197-230. http://dx.doi.org/10.1007/978-3-642-02550-1_10

[14] Westerkamp, C. (1991) Honey Bees Are Poor Pollinators-Why? Plant Systematics and Evolution, 177, 71-75. http://dx.doi.org/10.1007/BF00937827

[15] Kearns, C.A. and Inouye, D.W. (1997) Pollinators, Flowering Plants and Conservation Biology. BioScience, 47, 297307.

[16] Stanley, R.G. and Linskens, H.F. (1974) Pollen: Biology Biochemistry and Management. Springer, Berlin. http://dx.doi.org/10.1007/978-3-642-65905-8

[17] Dudash, M.R. and Fenster, C.B. (2000) Inbreeding and Out-Breeding Depression in Fragmented Populations. In: Young, A. and Clarke, G., Eds., Genetics, Demography and Viability of Fragmented Populations, Cambridge University Press, Cambridge, 35-53. http://dx.doi.org/10.1017/CBO9780511623448.005

[18] Lamont, B.B., Klinkhamer, P.G.L. and Witkowski, E.T.F. (1993) Population Fragmentation May Reduce Fertility to Zero in Banksia Goodie-A Demonstration of the Allee Effect. Oecologia, 94, 446-450. http://dx.doi.org/10.1007/BF00317122

[19] Hermanutz, L., Innes, D., Denham, A. and Whelan, R. (1998) Very Low Fruit: Flower Ratios in Grevillea (Proteaceae) Are Independent of Breeding System. Australian Journal of Botany, 46, 465-478. http://dx.doi.org/10.1071/BT97046

[20] Dorken, M.E. and Eckert, C.G. (2001) Severely Reduced Sexual Reproduction in Northern Populations of a Clonal Plant, Decodon verticillatus (Lythraceae). Journal of Ecology, 89, 339-350.

[21] Xie, C.Y., Dancik, B.P. and Yeh, F.C. (1991) The Mating System in Natural Populations of Thuja orientalis. Canadian Journal of Forest Research, 21, 333-339. http://dx.doi.org/10.1139/x91-041

[22] Lee, S.L. (2000) Mating System Parameters of Dryobalanops aromatic Gaertn. f. (Dipterocarpaceae) in Three Different Forest Types and a Seed Orchard. Heredity, 85, 338-345. http://dx.doi.org/10.1046/j.1365-2540.2000.00761.X

[23] Ibidapo, V.O. (2004) Preliminary Study of Some Phenological Characters of Afzeliaafricana FRIN, Seminar Series, April 28.

[24] Albrechor, J. and Oloo, W.O. (1993) Kenya Forestry Seed Centre: A Project Concept and Its Contribution towards Development. Forest Genetic Resources Information No. 21, FAO, Rome, 10-17. 
Scientific Research Publishing (SCIRP) is one of the largest Open Access journal publishers. It is currently publishing more than 200 open access, online, peer-reviewed journals covering a wide range of academic disciplines. SCIRP serves the worldwide academic communities and contributes to the progress and application of science with its publication.

Other selected journals from SCIRP are listed as below. Submit your manuscript to us via either submit@scirp.org or Online Submission Portal.
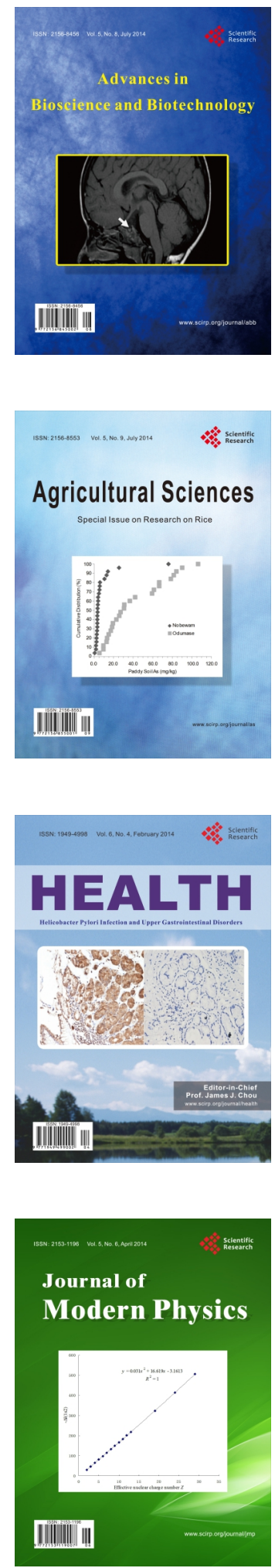
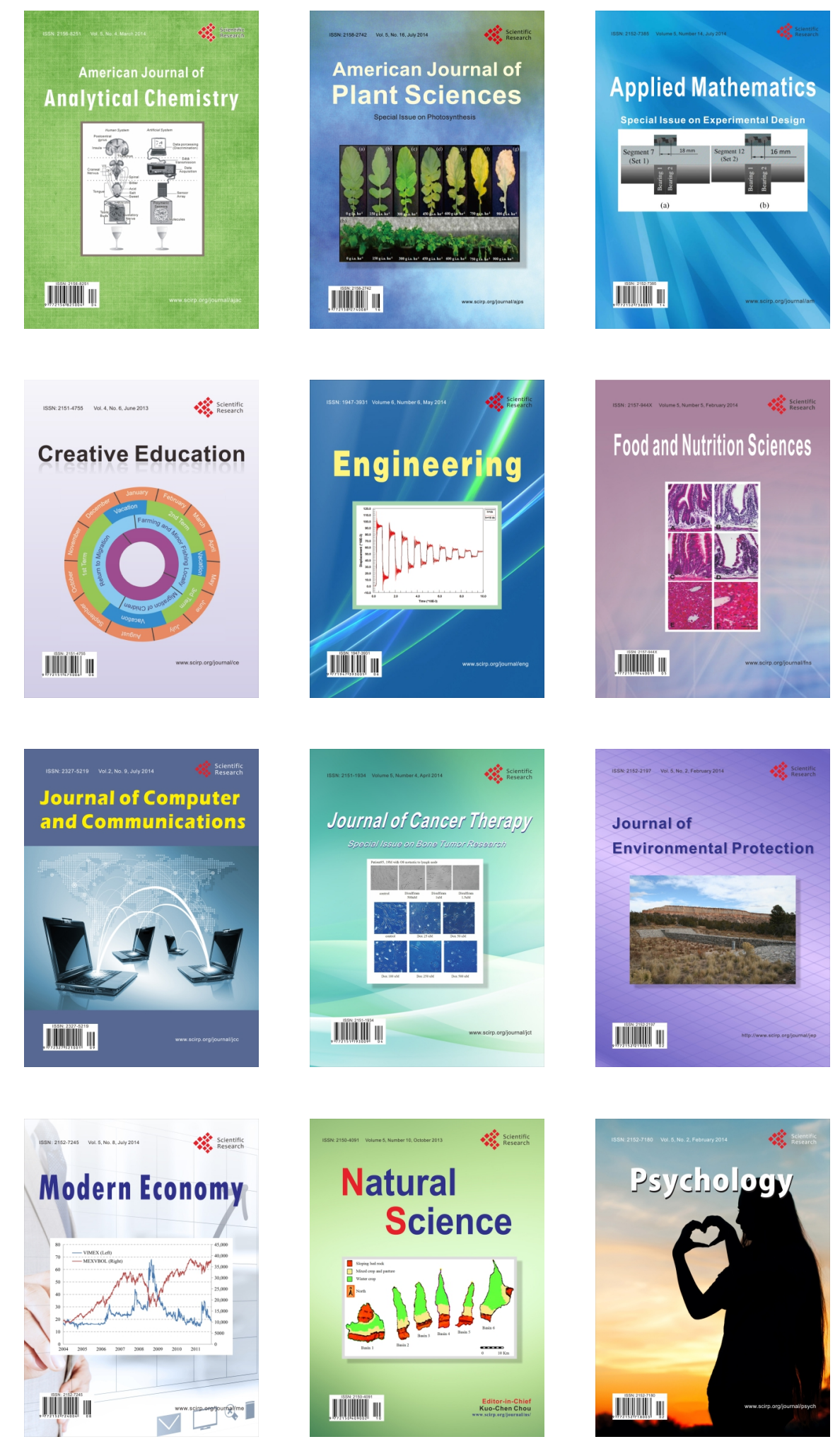